\title{
Residue on Floor of Mouth
}

National Cancer Institute

\section{Source}

National Cancer Institute. Residue on Floor of Mouth. NCI Thesaurus. Code C127215.

A finding of oral residue remaining on floor of mouth after an individual swallows. 